\title{
Errata for Biological \& Pharmaceutical Bulletin
}

\begin{tabular}{c|c|c|c|c}
\hline \hline Vol. & Page & Line & Error & Correction \\
\hline 27 & 1140 & Author's name & Maskut Coşkun & Correction \\
\hline \hline Vol. & Page & $1509-1514$ & $\begin{array}{l}\text { It has come to our attention that this enzyme was previously expressed and its biochemical transferase activity was } \\
\text { determined by Ten Hagen } \text { et al. }{ }^{\text {1) }} \text { Therefore, our paper does not represent the first biochemical characterization of } \\
\text { this isozyme. Also, the gene encoding this isoform should be referred to as "pgant3", as designated in the afore- } \\
\text { mentioned reference. } \\
\text { 1) Ten Hagen K. G., Tran D. T., Gerken, T. A., Stein D. S., Zhang Z., J. Biol. Chem., 278, 35039-35048 (2003). }\end{array}$ \\
\hline
\end{tabular}

